\title{
Body Weight Evolution of Tsigai and Tsigai and Berrichon du Cher Crossbred Lambs
}

\author{
MIHAI MARIAN BORZAN ${ }^{1 *}$, ADRIAN CIMPEAN ${ }^{1}$, DANA PUSTA ${ }^{1}$, LIVIU BOGDAN², ALEXANDRA TABARAN ${ }^{1}$, EMOKE PALL ${ }^{2}$, \\ ATTILA MATE ${ }^{3}$, MIHAI CENARIU ${ }^{2}$, IOAN PASCA ${ }^{1}$ \\ 'University of Agricultural Sciences and Veterinary Medicine Cluj, Department of Animal Productions and Food Safety, 3-5 Calea \\ Manastur 3-5 Str., 400372, Cluj Napoca, Romania \\ 2University of Agricultural Sciences and Veterinary Medicine Cluj, Department of Clinics, 3-5 Calea Manastur 3-5 Str., 400372 , \\ Cluj Napoca, Romania \\ ${ }^{3}$ SCDA Turda, 27 Agriculturii Str., Turda, Romania
}

The Berrichon du Cher breed is a French meat sheep breed, specialized in production of high-quality meat. The demand of the EU market for the sheep meat is focused, especiallyin the western countries, on the high quality cuts of the sheep meat and the demand very low on unspecialized meat breeds like the local Tsigai breed. In order to improve the production efficiency Berrichon du Cher rams were crossed with Tsigai ewes. The lambs were compared with purebred igai lambs to evaluate daily weight gain from birth to 120 days. The daily weight gain was superior in the hybrid lambs compared with purebred lambs.

Key words: Berrichon du Cher, body weight, daily weight gain, Tsigai

Agricultural surface of Romania have a good potential in the production of sheep meat. In Romania, sheep and goats regularly are raised under extensive system, which imply low operation costs [1,2] Romania ranks 5th place in Europe in terms of sheep meat production with a share of $8 \%$ from the total UE-27 and according to FAO statistics, 4th position in Europe regarding sheep and goat's livestock $[3,4,5]$. According to data from Eurostat in December 2016 the Romanian national flock reared at 9.88 million head, with a national breeding flock of 8.4 million head. In Romania the breed structure is dominated by indigenous rustic breeds, such as the Turcana, Tsigai and Merino breeds $[6,7]$. Using breeds specialized in meat production (like Berrichon du Cher breed), as paternal lines, with purebred local breed (like Tsigai breed), as maternal lines, the heterosis effect occurs. In this way, the parental purebreds aren't affected (Berrichon du Cher and Tsigai) and the F1 hybrids can be used to sustain the farmer's productions for the EU market. Our studies had focused on evaluation of the heterosis effect by crossing Berrichon du Cher rams with Tsigai ewes regarding the weight of the resulting lambs at birth, 21 days, 50 days, 90 days and 120 days. We have formulated two hypotheses, according to the null hypothesis, the body weight of the crossbred Tsigai ewes with Berrichon du Cher rams and purebred Tsigai lambs is equal, regardless of the moment when the weighting is performed. According to the hypothesis H1the body weight of the crossbred Tsigai with Berrichon du Cher and purebred Tsigai lambs is different, regardless of the moment when the weighting is performed.

\section{Experimental part}

Materials and methods

The research has been carried out in 2015-2016 in a flock consisting of 100 purebred Tsigai ewes $(n=100)$. After estrus synchronization, 50 ewes were crossed with Berrichon du Cher rams and the other 50 with Tsigai rams. The resulting lambs were kept in similar conditions (feeding, housing, etc). The lambs were divided in two batches. The first batch consisted on a flock of purebred Tsigai lambs $(n=50)$ and the second consisted on a flock of F1 lambs (Tsigai ewes and Berrichon du Cher rams, $n=48$ ). The body weight of the lambs was evaluated at birth and after 21, 50, 90 and 120 days. The results were statistical evaluated using ANOVA test and t-Test. The analysis considered the daily weight gain, the comparative evaluation of body weight concerning the age, sex and purebred lams with F1 crossed lambs.

\section{Results and discussions}

The Berrichon du Cher breed has never been used before in crossings with the local Tsigai breed. This is an original study and presents preliminary data regarding the results of the crossings between Tsigai breed with Berrichon du Cher breed compared with the evolution of the purebred Tsigai. The research was conducted on 100 ewes randomly assigned in two experimental groups. After estrus synchronization the ewes were naturally mated with rams. The ewes from the first batch (Tsigai, $n=50$ ) were mated with Berrichon du Cher rams (batch I). A total of 46 ewes were diagnosed as pregnant by ultrasound examination and lambed, and 48 hybrid lambs $(n=48)$ resulted (the difference was recorded as abortion). From the second batch (control batch II, $n=50$ ), ewes were naturally mated with Tsigai rams, 47 lambed and 50 purebred lambs $(n=50)$ resulted (the difference was recorded as abortion). All the pregnant ewes were assisted to parturition; the resulted lambs were weighted immediately after parturition and identified with ear tags in the first day after birth. The sex ratio for crossbred and purebred lambs are different, more than half were females and the share of hybrid males was higher than the one registered in the purebred Tsigai batch (fig. 1).

Following the statistical analysis, we obtained superior results for the F1 crossed lambs - males and females compared with the purebred Tsigai lambs concerning the daily weight gain and the body weight evolution between the two batches. The average body weight of crossbred lambs (Tsigai and Berrichon du Cher) is higher than those of purebred Tsigai lambs from the control batch (at parturition, at 21, at5090 and 120 days). The data collected revealed that the male and female crossbreds from the testing batch recorded superior weights than the purebred

\footnotetext{
*email: mihai_borzan@yahoo.com, Phone: +40744621700
} 


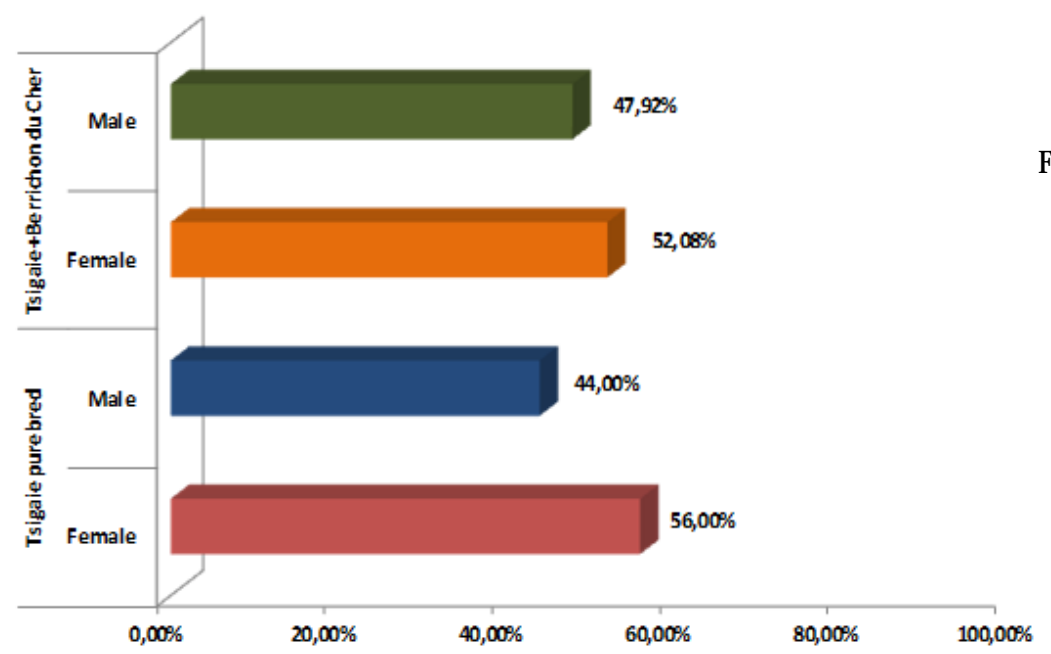

Figure 1. The share of crossbreds and purebreds lambs according to gender

Table 1

MEAN ( \pm STDV) OF THE BODY WEIGHT OF THE FEMALES AND MALES TSIGAI CROSSBRED WITH BERRICHON DU CHER AND TSIGAI PUREBRED LAMBS AT PARTURITION AND AFTER 21, 50, 90 AND 120 DAYS (kg)

\begin{tabular}{|c|c|c|c|c|c|}
\hline Mean \pm STDV & W0 $(\mathrm{kg})$ & W21(kg) & W50(kg) & W90(kg) & W120(kg) \\
\hline Tsigai purebred (females) & $3.62 \pm 0.35$ & $7.08 \pm 0.64$ & $12.77 \pm 1.0$ & $17.50 \pm 0.82$ & $22.05 \pm 0.94$ \\
\hline Tsigai purebred (males) & $3.53 \pm 0.47$ & $7.09 \pm 1.00$ & $12.45 \pm 1.16$ & $17.41 \pm 1.06$ & $22.05 \pm 1.14$ \\
\hline Tsigai and Berrichon du Cher (females) & $4.15 \pm 0.81$ & $8.85 \pm 0.87$ & $14.30 \pm 0.82$ & $21.16 \pm 1.07$ & $25.07 \pm 1.14$ \\
\hline Tsigai and Berrichon du Cher (males) & $4.48 \pm 0.31$ & $8.83 \pm 0.69$ & $14.44 \pm 0.99$ & $21.38 \pm 1.10$ & $25.72 \pm 1.21$ \\
\hline
\end{tabular}

W 0, body weight at birth, W21, body weight at 21 days, W50 body weight at 50 days, W90, body weight at 90 days, W120, body weight at 120 days

Table 2

AVERAGE AND STANDARD DEVIATION OF THE DAILY WEIGHT GAIN OF THE FEMALES TSIGAI CROSSBRED WITH BERRICHON DU CHER AND TSIGAI PUREBRED LAMBS AT 21, 50, 90 AND 120 DAYS (kg)

\begin{tabular}{|c|c|c|c|c|}
\hline Mean \pm STDV & DW21(g) & DW50(g) & W90(g) & DW120(g) \\
\hline Tsigai purebred (females) & $0.16 \pm 0.02$ & $0.20 \pm 0.03$ & $0.12 \pm 0.03$ & $0.15 \pm 0.03$ \\
\hline Tsigai purebred (males) & $0.17 \pm 0.03$ & $0.18 \pm 0.02$ & $0.12 \pm 0.03$ & $0,15 \pm 0.03$ \\
\hline Tsigai and Berrichon du Cher (females) & $0.22 \pm 0.03$ & $0.19 \pm 0.03$ & $0.17 \pm 0.02$ & $0.13 \pm 0.03$ \\
\hline Tsigai and Berrichon du Cher (males) & $0.21 \pm 0.03$ & $0.19 \pm 0.02$ & $0.17 \pm 0.02$ & $0.14 \pm 0.04$ \\
\hline
\end{tabular}

DW 21, daily weight gains at 21 days, DW50, daily weight gains at 50 days, DW 90, daily weight gain at 90 days, DW 120, daily weight gain at 120 days

males and females Tsigai lambs from the control batch (II) (table 1, 2).

Concerning the body weight analysis at parturition of the control batch (II) and the test batch (I), the ANOVA test revealed that $F>F$ crit, meaning $25.46>4.019$, so the null hypothesis is rejected and the $\mathrm{H}_{1}$ hypothesis is accepted. The t-Test confirmed that $t$ Stat $\geq t$ Critical two-tail, (4.69 $\geq 2.03$ ), fact that reinforces the hypothesis according to the body weight at parturition of the crossbred Tsigai lambs is different that the weight of purebred Tsigai lambs. After 21 days the results of the weights revealed that $F>F$ crit, in our case $62.58>4.01$. So, the $\mathrm{H}_{\text {hypothesis is rejected }}$ and the $\mathrm{H}_{1}$ hypothesis is accepted. The $\mathrm{H}_{1}$ hypothesis states that the body weight at 21 days of the crossbred Tsigai lamb's x Berrichon du Cher is different to the weight of purebred Tsigai lambs. The t-Test analysis revealed that $\mathrm{t}$ Stat $\geq \mathrm{t}$ Critical two-tail, in our research $7.73 \geq 2.01$, that body weight at 21 days of the crossbreds Tsigai lamb's $x$ Berrichon du Cher is different to Tsigai purebred lambs.
The statistical analysis with ANOVA single factor at 50 days for the lambs revealed that $F>F$ crit, in our study being $43.78>4.01$ and confirms the hypothesis 1 . The t-Test reinforced the results obtained with ANOVA (t Stat $\geq t$ Critical two-tail: $6.39 \geq 2.01$ ). After 90 days ANOVA (184.25 $>4.01, \mathrm{~F}>\mathrm{F}$ crit) confirm the $\mathrm{H}_{1}$, confirmed also with tTest: t Stat $\geq$ t Critical two-tail ( $12.69 \geq 2.02)$. At 120 days the body weight analysis sustains the difference betw een the average of the two batches. Another similar study provides data about purebreds Tsigai and purebred Berrichon du Cher, or results obtained after crossings with other breeds, but our current preliminary study is the first research that records the results between the tw o breeds. Our results for the purebred Tsigai sheep were similar to those found by other researchers [8]. For the crossbreds, the productions were superior compared with purebreds, but similar to other crossbreds [3]. Daily weight gains for the purebred Tsigai and hybrid Tsigai and Berrichon du Cher lambs revealed a progressive development. The hybrids 
presented a substantial body weight compared with purebreds after birth and this trend has been maintained (21, 50, 90 and 120 days). The batch I consisting of hybrid lambs presented superior weights during the entire analyzed period, compared with the purebred Tsigai lambs.

\section{Conclusions}

The study confirmed the compatibility of crossing the two breeds to produce viable lambs, with a superior hybrids weight compared with purebred Tsigai. In our study we scored more females than males in the produced lambs, with more than a half in the both batches $(56.00 \%$ in purebreds Tsigai and $52.08 \%$ in hybrids).

There result shows statistically significant differences $(p \leq 0.05)$ between the weights at parturition and after 21 , 50,90 and 120 days. The daily weight gain was superior in the hybrid lambs compared with purebred Tsigai lambs. The research confirmed the superior weights of lambs obtained in F1 between the Berrichon du Cher and Tsigai breed.
Acknowledgements: This work has benefited from financial support through the PN-II-PT-PCCA-2013-4-1239 project, No: 152/01.07.2014, "Obtaining the Romanian meat lamb - OVICARO.

\section{References}

1.GRODEA, M., IULIANA, I., MPRA No. 69264, 2016.

2.BELIBASAKI, S., SOSSIDOU, E.N., GAVOJ DIAN, D., Anim. Sci. and Biotech., 45 (2), 2012, p. 278-284

3.FAO STATISTICAL YEARBOOK, E-ISBN 978-92-5-108168-6, 2014.

4.PASCAL, C., NECHIFOR, I., Lucrari Stiintifice Seria Zootehnie, no. 61, 2014.

5.REP. OF THE ROM. NAT. AG.FOR GEN. IMPR. AND REPR. IN ANIM. HUSB. FOR THE YEAR 2010, 2012.

6.ILISIU, E., DARABAN, S., RADU, R., PADEANU, I., ILISIU, V-C., PASCAL, C., RAHMANN, G., Landbauforsch Appl Agric Forestry Res 63(2):, 2013, p. 161-170.

7.SAUER, M., PADEANU, I., NECULAI, D., ILISIU, E., RAHMANN, G., SAUER, W.I., VOIA, S.O., GAVOJ DIAN, D., Landbauforsch Appl. Agric. Forestry. Res., 2015.

8.MIRESAN, E., POP, A., POPA, O. Lucr.St. I.A.C.N., no. 2, 1979, p. 143146.

Manuscript received: 16.01 .2019 